\title{
CZY UZASADNIONY JEST POSTULAT UWZGLĘDNIENIA SPECYFIKI NAUK HUMANISTYCZNYCH I SPOŁECZNYCH PRZY OCENIE JEDNOSTEK NAUKOWYCH I BADACZY? MIĘDZY PEER REVIEW A BIBLIOMETRIĄ I NAUKOMETRIĄ
}

\begin{abstract}
Jerzy Marian Brzeziński, Czy uzasadniony jest postulat uwzględnienia specyfiki nauk humanistycznych i społecznych przy ocenie jednostek naukowych i badaczy? Między peer review a bibliometriq inaukometria [ls the postulate to take into account the specificity of the humanities and social sciences during the evaluation of scientific units and researchers justified? From peer review to bibliometrics and scientometrics], edited by Z. Drozdowicz, S. Sztajer ${ }_{\text {,IC }}$ Złowiek i Społeczeństwo", vol. XXXIX, Poznań 2015, pp. 9-30. Adam Mickiewicz University Press. ISBN 978-83-232-2953-7, ISSN 0239-3271.

A significant element of institutional functioning of science is evaluating the functioning of scientific units (university faculties, research institutes) by institutions established by the state. In Poland such an evaluating body is The Committee for Evaluation of Scientific Units, which by means of standardised procedures - using a four-point scale $(+A, A, B, C)$ - assesses scientific units every four years. The author considers the question: Should there be different criteria for evaluating scientific units conducting research in the field of the humanities and social sciences from those used in the field of science? In the author's view, in order to obtain valid and reliable evaluation it is necessary to take into account the specificity of the humanities and social sciences.
\end{abstract}

Jerzy Marian Brzeziński, Uniwersytet im. Adama Mickiewicza w Poznaniu, Instytut Psychologii, ul. Szamarzewskiego 89, 60-568 Poznań, Poland; Wydział Nauk Humanistycznych i Społecznych PAN, Warszawa, Poland

${ }^{1}$ Prof.drhab. Jerzy Marian Brzeziński, czł.rzecz.PAN; e-mail: brzezuam@amu.edu.pl. 


\section{Wprowadzenie}

Trzeba chyba zacząć od tego, że przedstawiciele „prawdziwej” nauki (science) uważają, że to oni powinni wyznaczać standardy oceny dokonań instytucjonalnie uprawianej praktyki badawczej i - w konsekwencji - mieć decydujący wpływ na podział środków finansowych przeznaczonych na funkcjonowanie jednostek naukowych i badaczy w tej sferze. Mało tego, uważają, że humanistyka i dyscypliny społeczne (być może z wyjątkiem ekonomii czy psychologii) należą do porządku sztuki i nie zasługują na miano „prawdziwej” nauki. Że nie są to tylko - niepotwierdzone twardymi faktami - pomówienia, wystarczy zwrócić uwagę na uporczywe trwanie (począwszy od KBN, przez Radę Nauki, na KEJN kończąc) przy tym, aby priorytetowo traktować publikacje zamieszczane w czasopismach lokowanych na jednej tylko liście: JCR (popularnie zwanej listą filadelfijską²) firmy Thomson Reuters, oraz podejmowanie prób zwiększania środków z rozdziału „nauka” budżetu państwa na doraźne finansowanie badań realizowanych w ramach grantów NCN i NCBiR. Owo zwiększanie środków przeznaczonych na finansowanie zatomizowanych zadań realizowanych w krótkiej perspektywie czasowej (od roku do 3-4 lat - czas trwania typowych projektów NCN: OPUS czy PRELUDIUM) ma się odbywać kosztem zmniejszania środków przeznaczanych na działalność statutową jednostek naukowych. Na owym nadmiernym przecenianiu dokonań publikacyjnych w czasopismach z listy JCR (od 15 do 50 pkt za jedną publikację) vs. publikacje z pozostałych list ministerialnych (B i C - od 1 do 10 pkt za jedną publikację; także tych ogłaszanych w uznanych światowych czasopismach z zakresu humanistyki, np. Mind czy Erkenntnis) oraz deprecjonowaniu monografii (20 albo 25 pkt, i to niezależnie od jej wartości naukowej - wy-

${ }^{2}$ To właśnie fizyk Andrzej Kajetan Wróblewski zaproponował tę nazwę na listę czasopism opracowaną przez Institute for Scientific Information ISI w Filadelfii. Jak pisał w Forum Akademickim (4/1999): „Tę listę przy jakiejś okazji nazwałem skrótowo listą filadelfijską [prawodopodobnie w artykule opublikowanym w Forum Akademickim 9/1998 - J.M.B.) i owa nazwa przyjęła się już w Polsce”. Od jakiegoś czasu właścicielem listy master i jej pochodnych (Thomson Reuters Master Journal List: 17 tys. tytułów) jest firma Thomson Reuters. Poprawnie tę nazwę należy przypisać tej właśnie liście. Zaś lista czasopism z co roku odnawianymi wartościami współczynnika IF publikowana jest w roczniku (aktualnie dostępny jest tom za 2014 r.). Journal Citation Index funkcjonuje pod skróconą nazwą listy JCR (w Polsce oficjalnie jako Lista A MNiSzW). Lista master dostępna jest pod adresem: http://scientific.thomsonreuters.com/cgi-bin/jrnlst/jloptions.cgi?PC=Master [4.09.2015]. 
starczy, by miała ona objętość co najmniej 6 arkuszy autorskich) korzystają przede wszystkim przedstawiciele świata nauk ścisłych, biologicznych, medycznych i technicznych. Moim zdaniem to arbitralne przyznawanie co jakiś czas (najpierw było 10-24 pkt, następnie: do 30 pkt, a obecnie: 1550 pkt) coraz większej liczby punktów za publikacje z listy JCR nie miało nigdy solidnego i przekonującego uzasadnienia. Równie dobrze można by się spodziewać, że KEJN niebawem ogłosi, iż będzie obowiązywała nowa punktacja: od 30 (koniecznie powyżej „wyceny” monografii) do 100 pkt.

Głównym, a tak naprawdę jedynym intersubiektywnie dostępnym środkiem informowania społeczności naukowej o rezultatach badań naukowych są monografie i artykuły ogłaszane w specjalistycznych czasopismach, naturalne więc staje się znalezienie odpowiedzi na pytanie o ocenę jakości artykułów i monografii. Jeśli chodzi o ocenę jakości artykułów powstałych w środowisku określonej dyscypliny naukowej czy jednorodnej grupy dyscyplin, to odwołujemy się do miar bibliometrycznych, które - w sposób zobiektywizowany - pozwalają na odróżnienie czasopism zajmujących wyższą pozycję w rankingu od tych, które zajmują pozycję niższą. Jeżeli badacz A publikuje swoją pracę w czasopiśmie zajmującym na tej swoistej liście rankingowej wyższą pozycję aniżeli czasopismo, w którym publikuje badacz B, to - pośrednio i zdając sobie sprawę z ryzyka uproszczenia, gdybyśmy zadowolili się taką „metryczną” miarą sukcesu publikacyjnego możemy uznać pracę badacza A za bardziej wartościową (czy wpływową w danej dyscyplinie naukowej, z którą związane jest dane czasopismo) od pracy badacza B. W rzeczywistości nie jest to takie proste i o to toczą się, także w Polsce, spory. I wcale nie jestem pewien, czy będą one w najbliższej przyszłości rozstrzygnięte w sposób, który zadowoli wszystkich uczestników tych sporów. Można jednak próbować szukać w miarę dobrego rozwiązania.

Znacznie bardziej kłopotliwa jest sytuacja oceny jakości monografii. Tu, w odróżnieniu od czasopism, brak jakichś, mniej czy bardziej doskonałych, list i rankingów.

\section{Najważniejsze są artykuły publikowane w czasopismach naukowych i monografie}

Zanim przedstawię własne propozycje rozwiązania problemu niedyskryminującego nauki humanistyczne i społeczne (dalej: NHS), spróbuję uporządkować problemy związane z oceną czasopism naukowych: 
1. Ustalenie list czasopism i zakresu punktacji: czasopisma o profilu humanistycznym i społecznym vs. czasopisma o profilu ścisłym, przyrodniczym, medycznym i technicznym.

2. Ustalenie kryteriów oceny monografii i podręczników akademickich.

Ad. 1. Dyskryminacyjne podejście do czasopism humanistycznych i części czasopism społecznych (i to tych uznanych w świecie i o wcale nie mniejszej wartości naukowej - o ile rzecz jasna zechcemy uznać humanistykę za naukę) budziło i budzi słuszny protest przedstawicieli nauk humanistycznych. O ile w naukach przyrodniczych, ścisłych czy technicznych publikowanie w języku angielskim jest czymś oczywistym, o tyle w naukach humanistycznych i społecznych wcale tak nie jest. W typowej nauce humanistycznej, jaką jest historia, naturalnym językiem jest język danego kraju. Jak podaje badacz tej problematyki, Władysław M. Kolasa: „dla historii udział języka narodowego waha się w przedziale 95,6-98,8\% (Francja 98,8; USA 98,8; W. Brytania 98,7; Włochy 98,7; Niemcy 96,1; Polska 96,0; Hiszpania 95,8; Rosja 95,6)” (Kolasa, 2011; za: Kulczycki, 2014, s. 124). Wspomnę w tym kontekście o dwóch krytycznych artykułach naszych wybitnych filozofów: Andrzeja Wiśniewskiego (2006) i Jana Woleńskiego (2013) polemicznie z Jerzym Wilkinem (2013). Patrząc na daty ich druku, możemy stwierdzić, że mimo upływu lat nic się nie zmieniło. Nadal to, co dobre dla nauk ścisłych, przyrodniczych i technicznych, musi być też dobre dla nauk humanistycznych!

W pełni podzielam stanowisko J. Wilkina, że właściwa (uwzględniająca specyfikę poszczególnych dziedzin nauki, a zatem i właściwych dla nich języków wyrażania efektów badań naukowych) ocena bibliometryczna czasopism naukowych ma podstawowe znaczenie i dla funkcjonowania instytucji naukowych, i dla awansów naukowych poszczególnych badaczy:

Ranking punktowy czasopism naukowych, podobnie jak i parametryzacja jednostek naukowych, jest próbą obiektywizacji ich jakości i pozycji na potrzeby pragmatyki postępowania przy podziale środków finansowych na naukę. Chodzi o wypracowanie przejrzystych i obiektywnych podstaw podziału funduszy publicznych, służących finansowaniu jednostek naukowych, zespołów i projektów badawczych, a także ocenie osiągnięć naukowych, zarówno poszczególnych badaczy, jak i instytucji. Obecnie parametryzacja jednostek w dużym stopniu zależy od klasyfikacji czasopism. Z parametryzacją wiąże się kategoryzacja, za którą idą pieniądze budżetowe. Można przyjąć, że punkty przyznawane czasopismom stanowią istotną część fundamentu dobrobytu bądź przyczyn upadku jednostek naukowych (Wilkin, 2013, s. 46). 
Wszystkie problemy, jakie rodzą się na styku NHS i pozostałych nauk, biorą się z tego, że instytucjom (i osobom nimi zarządzającym) odpowiedzialnym za politykę naukową państwa nie udało się zaproponować środowisku stabilnych i jasnych ram prawnych.

Sięgając w dość odległą przeszłość Komitetu Badań Naukowych (lata 90. XX wieku; byłem w jego pierwszym składzie), gdy powstawały zręby oceny parametrycznej jednostek naukowych i budowano pierwsze wystandaryzowane listy czasopism naukowych (wspomniana wyżej lista filadelfijska i lista czasopism krajowych), widać, że już wówczas rodziły się napięcia. Próbowano je załagodzić, gdy w czasach Rady Nauki (następczyni KBN) MNiSzW wprowadzono - tylko dla grupy NHS (!) - trzecią listę: ERIH. Nie traktowano jej jednak jako równoważnej z listą filadelfijską. Była ona (i jako lista JCR nadal jest) listą czasopism z grupy science (z uwzględnieniem nauk społecznych, np. psychologii), a jej właściciel - dziś firma Thomson Reuters dla czasopism z zakresu sztuki i humanistyki skonstruował odrębną bazę czasopism: Arts \& Humanities Citation Index, jednak i ona jest niepełna.

Niestety lista ERIH, a także jej, od lipca 2014 r., bogatsza o czasopisma z nauk społecznych lista ERIH Plus nie spełnia pokładanych w niej przez badaczy z kręgu NHS nadziei. Baza ERIH Plus rejestruje bowiem jedynie nadsyłane do niej przez redakcje zgłoszenia tytułów czasopism spełniających kilka wyłącznie formalnych kryteriów (o czym pisze Emanuel Kulczycki na swojej stronie internetowej i prezentuje swój „algorytm” rejestracji czasopisma na tej liście; to nie jest trudne! ${ }^{3}$ ):

ERIH Plus został rozszerzony o nauki społeczne (zobacz listę dyscyplin)4. Twórcy podkreślają, że ERIH Plus jest listą referencyjną czasopism publikowanych we wszystkich europejskich językach. Oznacza to, że ERIH Plus nie zamienia się w żadną bazę indeksującą czy ewaluacyjną.

Moim zdaniem należy zrezygnować z listy ERIH Plus, jako że nie jest ona żadną miarą odpowiednikiem list firmy Thomson Reuters. Już wątpliwa była lista ERIH (wystarczy popatrzeć na to, jakie pisma polskie się na niej znalazły), ale jej kontynuatorka tylko te wątpliwości pogłębiła. Nie zgadzam się więc z pierwszą częścią opinii wyrażonej przez E. Kulczyckiego, ale za to w pełni zgadzam się z drugą częścią jego oceny listy ERIH Plus:

Uważam, że przede wszystkim trzeba informację o ERIH-u Plus rozpowszechnić, gdzie się tylko da. Ponieważ polska polityka naukowa opiera się

${ }^{3}$ ekulczycki.pl/warsztat_badacza/erih-plus-zostal-uruchomiony/ [4.09.2015].

${ }^{4}$ https://dbh.nsd.uib.no/publiseringskanaler/erihplus/discipline/list [4.09.2015]. 
w dużej mierze o ERIH-a (rozporządzenie zawierające kryteria oceny habilitanta, parametryzacja jednostek i ocena czasopism, konkursy NCN-u), jest to sprawa istotna. Oczywiście kwestią otwartą pozostanie, jak w tej sprawie zachowają się odpowiednie gremia: czy uznają ERIH-a Plus za kontynuację ERIH-a (co wcale nie jest takie oczywiste) i czy będą honorowały „bycie na ERIH-u Plus” jako „bycie na ERIH-u”. Uruchomienie ERIH-a Plus to bardzo dobra wiadomość [tej opinii nie podzielam - J.M.B.]. Może pojawić się jednak problem dewaluacji tej listy [i ja go dostrzegam - J.M. B.]. Jeśli na ERIH-u Plus 1/3 czasopism to będą czasopisma polskie (a w sumie o to chodzi w listach referencyjnych), to pojawi się pytanie o to, jak traktować takie „indeksowanie na ERIH-u Plus”.

Co należy zatem zrobić, aby rozwiązać nabrzmiały problem? Dobrym rozwiązaniem byłoby zwiększenie liczby list. Nie bójmy się tego. Oprócz listy JCR, którą trzeba zachować, należy wprowadzić listę SCOPUS firmy Elsevier i jej produkt SCImago [pełna nazwa: SCImago Journal Rank (SJR) Indicator] dający wgląd w listę prawie 30 tys. czasopism, w tym przywołane przeze mnie tytuły z filozofii: Erkenntnis i Mind oraz ponad 400 innych z tej dyscypliny, z przypisanymi jej 10 kryteriami $^{5}$. To da szanse postulowanego wyżej (Kulczycki, 2014, s. 123, z jego postulatem „równości zasad”) zrównoważenia ocen czasopism z różnych dziedzin nauki. Należy podejmować działania mające na celu wprowadzenie zamiast ERIH Plus listy SCOPUS. Może można by wprowadzić jeszcze jakąś poważną listę czasopism?

Odrębnym problemem, który nie został dotąd rozwiązany, jest kształt listy krajowej czasopism (lista B). Ta dotychczasowa jest, mimo podejmowanych prób jej udoskonalania, nadal ułomna. Na razie czekamy na propozycje uwzględniające Polski Współczynnik Wpływu (PWW) dla polskich czasopism. Jego powstanie jest przesuwane z roku na rok. Jak pisał w tonacji optymistycznej J. Wilkin (2013, s. 53):

Wykorzystanie PWW wraz z PIF ${ }^{6}$ (którego znaczenie zapewne wzrośnie) pozwoli zbliżyć zasady oceny punktowej czasopism z części B listy do tej z części A (opartej na Impact Factor). Zakładamy, że już w 2013 roku Polski Współczynnik Wpływu zostanie wykorzystany do oceny czasopism wydawanych w języku polskim, co będzie miało, jak sądzę, znaczny wpływ na punktację czasopism części B. Zasady tej oceny zostaną prawdopodobnie ogłoszone w końcu marca 2013 roku [niestety, tak się nie stało - J. M.B.].

Podsumowując, chciałbym zgłosić kilka postulatów, które mają tę zaletę, że można - jeżeli się zechce, a życie pokazuje, że wcale tak być nie

${ }^{5}$ http://www.scimagojr.com/ [4.09.2015].

${ }^{6}$ PIF - Predicted Impact Factor. 
musi - zmieniając jedynie ustawę o finansowaniu nauki oraz rozporządzenia wykonawcze, wprowadzić je w życie.

Dziś nie tylko dokonując parametryzacji jednostek naukowych (KEJN), ale też oceniając dorobek pojedynczych badaczy w związku z przeprowadzanymi procedurami awansowymi (zwłaszcza: profesury i habilitacje) i konkursowymi (zwłaszcza: NCN i NCBiR) odwołujemy się do oceny dorobku naukowego, czy to zgromadzonego przez jednostkę naukową (w okresie 4 lat - KEJN), czy przez danego badacza/nauczyciela akademickiego (w czasie poprzedzającym wniosek awansowy). Ta ocena obejmuje publikacje: w 60-70\% w przypadku jednostek naukowych oraz prawie $100 \%$ w przypadku indywidualnych badaczy. Bywa i tak, w skrajnym, moim zdaniem bezprawnym postępowaniu, że dany wydział uczelni wyznacza dolną granicę sumy punktów, które musi zebrać dana osoba ubiegająca się o wszczęcie postępowania awansowego.

Niezmiernie ważne staje się wtedy właściwe ocenianie publikacji (zwłaszcza artykułów). Dziś - powtórzę - przedstawiciele NHS nie są traktowani tak samo jak przedstawiciele pozostałych nauk. Widać to wyraźnie w ocenie pozycji naukowej osoby ubiegającej się o grant w NCN preferencyjnie traktowane są publikacje w czasopismach z bazy Web of Science. Dodawanie, od pewnego czasu, także bazy ERIH nie poprawiło sytuacji, gdyż np. czasopisma socjologiczne (jako niehumanistyczne) nie były w tej bazie indeksowane.

Aktualnie posługujemy się w Polsce trzema listami:

- lista A - czyli lista JCR tworzona w bazie Web of Science (WoS); na której znajduje się 10230 czasopism;

- lista B - czyli lista krajowa (choć znajdują się na niej też czasopisma zagraniczne - dlaczego?); obejmuje 1854 czasopisma;

- lista C - czyli „stary” ERIH (czy będzie też uznawany ERIH Plus, tego nie wiemy); znajduje się na niej 4337 czasopism (dane za rok 2013 za: Wilkin, 2013, s. 47).

Z powodów wyżej wyłożonych (z konieczności skrótowo) proponuję:

Postulat 1. Wprowadzenie na listę A, obok JCR, także SCImago i wyrównanie wskaźników naukometrycznych dla obu baz. Idzie o to, aby czasopismom zajmującym podobną pozycję bibliometryczną na obu listach przyznać tyle samo punktów w ocenie naukometrycznej.

Postulat 2. Zniesienie listy C (ERIH czy ERIH Plus - z powodów wyżej przedstawionych). Cel jej wprowadzenia będzie lepiej realizowany przez listę SCImago; wpłynie to również na podniesienie poziomu czasopism krajowych. 
Postulat 3. Ograniczenie do niezbędnego minimum listę B (krajową) i opracowanie jej w trybie eksperckim; do tego celu można wykorzystać zespoły ekspertów powołane przez właściwe komitety naukowe PAN.

Mielibyśmy zatem tylko dwie listy: międzynarodową (lista A: JCR i SCImago) i krajową (lista B).

Ponadto w dużej liczbie drukowanych artykułów i przedstawionych przez jednostki naukowe i poszczególnych badaczy obok naprawdę dobrych, twórczych artykułów znajdują się także artykuły słabe, współtworzące nie prawdziwą naukę, ale „naukę śmieciową” (junk science). Dlatego też należałoby w ocenie uwzględnić tylko część „produkcji” naukowej poszczególnych badaczy. Myślę, że godnym uwagi jest pomysł przedstawiony przez Macieja Żylicza (2008):

W ocenie naukowej indywidualnej lub zbiorowej (np. ocena parametryczna) nie powinniśmy uwzględniać wszystkich prac opublikowanych, ale na przykład poddawać ocenie $25 \%$ prac, które sam autor w okresie oceny, np. nie krótszym niż 5 lat, będzie uważał za najważniejsze [podkr. - J. M.B.]. Może po paru latach takiej praktyki nasze środowisko samo dojdzie do wniosku, że opłaca się publikować mało, ale za to dobre prace.

Ad. 2. Rozwiązanie problemu właściwego oceniania monografii naukowych nie jest wcale proste. Nie wystarczy podnieść liczby punktów za monografie humanistyczne i społeczne (były nawet takie propozycje, aby to było 50-100 pkt), aby zrównoważyć - a tak sądzi spora część badaczy z obszaru nauk humanistycznych - oceny artykułów ogłaszanych drukiem w czasopismach z listy JCR z ocenami monografii. Ich zdaniem można by w ten sposób zniwelować efekt niedoszacowania, zwłaszcza naprawdę oryginalnych i bardzo dobrych monografii, wywołany nadmiernie wysoką punktacją artykułów z listy JCR. Jest to jednak błędna strategia, gdyż prowadzi do kolejnego, niepożądanego efektu przeszacowania słabych i lokalnych monografii. Jak zatem postąpić?

Zacznijmy od stwierdzenia, że dotychczasowe postępowanie jest niewłaściwe. Przez wiele lat nie zdołano uporać się z tym problemem, a kolejne propozycje (z ostatnią autorstwa KEJN) określenia, czym jest monografia ${ }^{7}$, wołają o pomstę do nieba. Jeżeli monografia wydana jest

7 Oto jej definicja zaczerpnięta z § 8.2: „Monografie naukowe [...] zalicza się do osiągnięć naukowych i twórczych jednostki naukowej, jeżeli spełniają łącznie następujące warunki: 1) stanowią spójne tematycznie, recenzowane opracowania naukowe; 2) zawierają bibliografię naukową; 3) posiadają objętość co najmniej 6 arkuszy wydawniczych; 4) są opublikowane jako książki lub odrębne tomy; 5) przedstawiają określone zagadnienie w sposób oryginalny i twórczy”. Zob. Rozporządzenie Ministra Nauki i Szkolnictwa Wyż- 
w języku polskim, a nie jest on językiem podstawowym dla danej dyscypliny, lub w języku innym niż angielski, niemiecki, francuski, hiszpański, rosyjski lub włoski, to jednostka zatrudniająca autora otrzymuje 20 pkt, a jeżeli w języku podstawowym dla danej dyscypliny, a także w językach: angielskim, niemieckim, francuskim, hiszpańskim, rosyjskim lub włoskim lub w języku polskim, gdy jest on językiem podstawowym dla danej dyscypliny, to jednostka otrzymuje 25 pkt. Kraj wydania i ranga wydawnictwa nie mają znaczenia. Mówiąc krótko, to, „co” znajduje się między okładkami, i to, „gdzie” zlokalizowane jest wydawnictwo, nie jest ważne. Przypisanie punktów następuje niejako automatycznie.

W ostatnio przeprowadzonej parametryzacji jednostek naukowych nikt nie był w stanie sprawdzić poziomu naukowego żadnej monografii - ocena typu peer review była wykluczona. Można było ująć w Karcie kompleksowej oceny jednostki naukowej dla grupy nauk humanistycznych i społecznych (i uzyskać 20-25 pkt) każdą „,syntezę introligatorską” wydaną przez tzw. wydawnictwa naukowe przeróżnych szkół i szkółek. Dodajmy jeszcze postulat zgłaszany przez środowiska z obszaru nauk społecznych (pedagodzy i socjologowie), aby za monografie (w sensie przytoczonym wyżej) uznawać także zamieszczane w Internecie raporty z badań. Tak szeroko otwarta furtka stanowiłaby zaproszenie dla tych, których prace nie zdołałyby przekonać co do ich poziomu naukowego recenzentów dobrych czasopism naukowych akceptujących prace w systemie blind-review. Mogłyby one natomiast nadal wydać „u siebie” (nawet w języku angielskim!) dowolną 6-arkuszową pracę. I jeszcze jedno ułatwienie dla takich praktyk - jednostka mogła (czy w następnej parametryzacji też będzie mogła?) przedstawić dużo (za dużo!) monografii, bo aż do 40\% wszystkich zgłoszonych do oceny publikacji (ich liczba równa jest $3 \mathrm{~N}$ ). Jeżeli przykładowo jakaś jednostka zatrudniała w okresie podlegającym ocenie 100 badaczy, to $3 \mathrm{~N}=3 \times 100=300.40 \%$ z 300 to 120. To bardzo dużo. Tak dużo, że trzeba być naiwnym, by spodziewać się, że będą to wyłącznie wybitne, czy nawet przeciętne, pozycje.

Moim zdaniem prowadzi to do przeszacowania wartości owych „syntez introligatorskich”. Znane są praktyki dzielenia dużych książek na 2-3 mniejsze. W ten sposób 20 pkt przemienia się w 40-60 pkt. I jest też druga strona tego samego medalu - „monografia naukowa”. Mamy bowiem ewidentne niedoszacowanie wartościowych monografii (i jest to poważny zarzut stawiany bibliometrycznemu podejściu do oceny monografii), a jed-

szego z dnia 13 lipca 2012 r. w sprawie kryteriów i trybu przyznawania kategorii naukowej jednostkom naukowym, Dz.U. poz. 877. 
nocześnie przeszacowanie słabych czy nawet bardzo słabych książek, ale też z „zaproszeniem” do popełniania oszustw.

Jaka jest więc moja propozycja? Obejmuje ona kilka elementów, które muszą być jednoznacznie rozstrzygnięte.

Po pierwsze, należy od nowa zdefiniować monografię. Moim zdaniem powinna to być praca naukowa:

- przygotowana przez jej autora (autorów) zgodnie ze standardami obowiązującymi w danej dyscyplinie naukowej, a więc zawierająca bibliografię oraz widoczny oryginalny wkład autora w rozwiązanie (przedstawienie) określonego problemu naukowego;

- obejmująca nie mniej niż 15 arkuszy wydawniczych (w NHS);

- wydana przez oficynę wydawniczą o ustalonej w środowisku pozycji. To, zdaję sobie z tego sprawę, nie jest łatwe do rozstrzygnięcia. Myślę jednak, że jest możliwe, przynajmniej w odniesieniu do wydawców krajowych, sporządzenie list wydawców znanych i szanowanych w środowisku danej dyscypliny naukowej. W szczególności nikomu bliżej nieznany wydawca szkółki udającej, że jest „wyższą”, na takiej liście by się nie znalazł. W ostatniej parametryzacji trzeba było takich egzotycznych wydawców akceptować, a nie trzeba było akceptować marnych naukowo czasopism. Wnoszę jedynie o to, by przy ocenie poziomu monografii postępować analogicznie, jak postępuje się przy ocenie artykułów zgłaszanych do druku w dobrych (z list: JCR czy SCImago) czasopismach naukowych;

- opiniowana przed drukiem przez kompetentnego w danym przedmiocie recenzenta, który powinien w swojej opinii wskazać na nowatorski charakter monografii (recenzja wydawnicza powinna być dołączona do egzemplarza książki). Zauważmy, że nie żąda się tu czegoś „ekstra”. Przecież w naprawdę dobrych czasopismach naukowych recenzenci (na ogół jest ich dwóch) muszą się m.in. wypowiedzieć na temat oryginalności przedstawionego $\mathrm{w}$ artykule rozwiązania i odniesienia do literatury przedmiotu (przede wszystkim tej najnowszej). Oczekuję zatem od monografii, że będzie ona pod względem merytorycznym - spełniała te same kryteria treściowe, co dobry artykuł naukowy. Nawiasem mówiąc, owa recenzja wydawnicza biorąc pod uwagę kompetencje i wnikliwość jej autora - mogłaby być wykorzystana w ocenie monografii.

Po drugie, trzeba ograniczyć liczbę monografii zgłaszanych przez jednostkę. Powody takiego posunięcia są dwa. Jeżeli mamy oceniać monografie w trybie peer review, to musi ich być niewiele. To, że dopuszcza się aktualnie, iż tych monografii można przedstawić aż (!) 40\% (w stosunku do $3 \times \mathrm{N}$ ), wyzwala wprost zjawisko inflacji i zwiększa możliwość wystąpienia 
nadużyć. Nie uważam też - z tych samych powodów co wyżej wyłożone aby jednostka mogła rozliczać się monografiami napisanymi przez badaczy, którzy nie są jej pracownikami, a jedynie wskazują jednostkę jako miejsce afiliacji (może ich być aż do 20\% wszystkich uwzględnionych przez jednostkę monografii). Moja sugestia, jak postąpić, aby ograniczyć występowanie niepożądanych zjawisk, jest taka, aby to jednostka sama wskazywała, które napisane przez jej pracowników monografie poddać ocenie. Tych publikacji, aby była im przyznana stosunkowo duża liczba punktów (np. w gradacji: 20-40-60 pkt), nie powinno być zbyt dużo. Proponuję, aby ją powiązać z wielkością N, np. do $\mathrm{N}=50$ - 5 monografii; $\mathrm{N}=50-100$ - 10 monografii; $\mathrm{N}=100-200-15$ monografii; powyżej $\mathrm{N}=200-20$ monografii. Jest to jednak tylko propozycja. Powinno się te liczby porównać z wynikami symulacji przeprowadzonej na danych z ostatniej parametryzacji.

Po trzecie, monografie powinny być oceniane w trybie peer review. Można by w tym celu wykorzystać wybrane recenzje wydawnicze.

Podobnie powinno się potraktować podręczniki akademickie (ale nie skrypty, materiały poglądowe czy poradniki).

\section{Dwa problemy}

Taka czy inna punktacja jest tylko jednym - przyznaję, że bardzo ważnym, ale tylko jednym - elementem bardziej złożonej układanki. Nie ogniskujmy naszej dyskusji tylko na jednym, nawet bardzo ważnym elemencie, bo nie znajdziemy satysfakcjonującego rozwiązania. Potrzebujemy całościowego rozwiązania. I o próbie jego skonstruowania chcę tu napisać.

Dwa problemy - potraktujmy je jako podstawowe - wymagają jednoznacznego rozstrzygnięcia, aby uzyskać rzetelny i trafny obraz dokonań jednostek naukowych oraz badaczy.

\subsection{Problem 1: Ustalenie trybu oceny oraz jej składników}

Jednym z najważniejszych problemów, przed którym stanie niebawem KEJN, jest rozstrzygnięcie trybu dokonywanej oceny. Można będzie postąpić jak dotychczas, co oznacza, że ocena będzie miała wyłącznie charakter naukometryczny. To, że kryterium IV było oceniane ekspercko (jego udział w całej ocenie wynosił w grupie NHS zaledwie 15\%) raczej nie miało większego (poza granicznymi przypadkami) wpływu na uzyskanie 
określonej kategorii. Myślę też, że było ono niedopracowane (Antonowicz i Brzeziński, 2013).

Nie ulega wątpliwości, że ocena jednostek naukowych w trybie wyłącznie bibliometrycznym jest stosunkowo łatwa. W zasadzie, gdyby dane przedstawiane przez jednostki naukowe były rzetelne, tj. pozbawione niezamierzonych błędów wynikających z niedbalstwa czy braku zrozumienia zasad, oraz gdyby nie podejmowano prób oszustwa, wtedy wystarczyłoby dobre oprogramowanie komputerowe. Zwolennicy tego czysto ilościowego (czy inaczej mówiąc: parametrycznego) podejścia do oceny kondycji naukowej jednostek naukowych podkreślają jego obiektywizm (niepoddawanie się subiektywnym, a przez to stronniczym ocenom ekspertów) i - co też istotne - niski koszt (nie trzeba opłacać dużego, nie tak łatwo osiągalnego zespołu ekspertów). Wady - ostatnio, zwłaszcza w środowisku NHS, dość stanowczo piętnowane - są na tyle znaczące, że nie sposób przejść nad nimi do porządku dziennego. Zdają się one ponadto przeważać nad zyskami i stają się powodem wprowadzenia drugiego, niejako konkurencyjnego trybu dokonywania ocen. I, myślę, że doprowadzą jeżeli nie do wycofania się z trybu bibliometrycznego, to przynajmniej do połączenia obu trybów: bibliometrycznego i peer review w przypadku dokonywania ocen jednostek naukowych. Jednak skala przedsięwzięcia (czas i koszty) skłania do, przynajmniej w części, posłużenia się bibliometrią, ale z dużą ostrożnością. Jeśli zaś idzie o ocenę osiągnięć naukowych poszczególnych badaczy, to jedynie za pomocą niektórych wskaźników naukometrycznych (np. indeksu h-Hirscha) - powinna być ona dokonana tylko w trybie peer review.

Poniższe uzasadnienia odejścia od radykalnej oceny typu parametrycznego można odnieść nie tylko do oceny jednostek naukowych, ale także do oceny pojedynczych badaczy.

Zacznę od najmocniejszego głosu w tej sprawie i to głosu pochodzącego nie ze środowiska NHS (jego głos sprzeciwu wobec podejścia czysto parametrycznego jest dobrze znany), ale ze środowiska hołdującego ocenom ilościowym - biologii (a konkretnie: biologii komórki). Ten głos zyskał bardzo silne wsparcie w całym naukowym świecie (uniwersytety i akademie oraz pojedynczy badacze, w tym liczna grupa noblistów). Idzie o dokument DORA, czyli San Francisco Declaration on Research Assessment. Putting science into the assessment of research z 16 grudnia 2012 r. (DORA, 2012; Bizukojć, 2014). Czytamy w nim w najistotniejszych dla tematu artykułu punktach: 


\section{General Recommendation}

1. Do not use journal-based metrics, such as Journal Impact Factors, as a surrogate measure of the quality of individual research articles, to assess an individual scientist's contributions, or in hiring, promotion, or funding decisions. [...]

\section{For institutions}

4. Be explicit about the criteria used to reach hiring, tenure, and promotion decisions, clearly highlighting, especially for early-stage investigators, that the scientific content of a paper is much more important than publication metrics or the identity of the journal in which it was published.

5. For the purposes of research assessment, consider the value and impact of all research outputs (including datasets and software) in addition to research publications, and consider a broad range of impact measures including qualitative indicators of research impact, such as influence on policy and practice $[\ldots]$

\section{For researchers}

15. When involved in committees making decisions about funding, hiring, tenure, or promotion, make assessments based on scientific content rather than publication metrics.

16. Wherever appropriate, cite primary literature in which observations are first reported rather than reviews in order to give credit where credit is due. 17. Use a range of article metrics and indicators on personal/supporting statements, as evidence of the impact of individual published articles and other research outputs.

18. Challenge research assessment practices that rely inappropriately on Journal Impact Factors and promote and teach best practice that focuses on the value and influence of specific research outputs.

Były redaktor naczelny „Science” - jednego z dwóch, obok „Nature”, czołowych czasopism naukowych świata - też odniósł się krytycznie do wartości IF czasopisma, traktowanego jako wskaźnik pozycji w nauce danego badacza:

The misuse of the journal impact factor is highly destructive, inviting a gaming of the metric that can bias journals against publishing important papers in fields (such as social sciences and ecology) that are much less cited than others (such as biomedicine). And it wastes the time of scientists by overloading highly cited journals such as Science with inappropriate submissions from researchers who are desperate to gain points from their evaluators (Alberts, 2013, s. 787). 
W Polsce, według mego rozeznania, z dużych instytucji deklarację DORA podpisała Fundacja na rzecz Nauki Polskiej:

Władze Fundacji na rzecz Nauki Polskiej zdecydowały się podpisać Deklarację z San Francisco, mając na względzie niepokojący fakt, że w środowisku naukowym od kilku lat rozwija się tendencja do sprowadzania jakości prac badawczych poszczególnych uczonych do oceny czasopism, w których ich osiągnięcia zostały opublikowane. Wprawdzie środowiska naukowe wiedzą, które czasopisma są w danej dyscyplinie najważniejsze, ale powinna to być wiedza pomocnicza, która nie zwalnia z oceny indywidualnych osiągnięć badawczych. [...]

Na podstawie doświadczenia w pracy nad systemami oceny parametrycznej w Komitecie Badań Naukowych oraz w Komisji Ewaluacji Jednostek Naukowych nie wykluczamy stosowania parametrów opartych o normalizowany w danej dziedzinie impact factor czasopism do oceny dużych jednostek naukowych. Z tych doświadczeń wynika, że gdy oceniana jednostka naukowa jest wystarczająco liczna (powyżej 60 naukowców), sumaryczny, normalizowany impact factor tej jednostki koreluje z jej cytowaniami, a w przypadku nauk eksperymentalnych także z poziomem finansowania badań naukowych z zewnętrznych źródeł. Taka korelacja nie występuje jednak przy ocenie małych jednostek, a tym bardziej indywidualnych zespołów badawczych oraz ich liderów! W tym wypadku należy bezwzględnie stosować system oceny peer review, w którym starannie wyselekcjonowani uczeni oceniają oryginalność indywidualnych osiągnięć naukowych innych badaczy, a pomocniczą rolę może spełniać liczba cytowań oraz wskaźnik $\boldsymbol{h}$ (podkr. - J. M. B.] (FNP, 2014).

Jestem przekonany, że ma miejsce pewne przesilenie, jeśli chodzi o nasycenie oceny jednostki naukowej i badacza różnymi wskaźnikami biblio-naukometrycznymi, że wracamy do ocen typu peer review - zwłaszcza gdy ocenie poddawane są osiągnięcia pojedynczych badaczy. Dotychczasowy, niemal w pełni bibliometryczny system ocen traci na znaczeniu. Trzeba zatem odnaleźć zagubionego ducha klasycznego uniwersytetu. Zwrócił na to uwagę w swoim jakże trafnym podsumowaniu Kongresu Kultury Akademickiej w Krakowie (20-22 marca 2014 r.) jego organizator Piotr Sztompka:

[...] zamiast opinii środowiskowej, jakościowej oceny przez academic peers, o statusie uczonego, a także całego uniwersytetu, decydują punkty przydzielane według arbitralnych administracyjnych kryteriów. Liczy się w stronach minimalną wielkość artykułu, za który należą się punkty. Liczy się w egzemplarzach dorobek naukowy. Recenzent aplikacji o grant czy wniosków awansowych zamiast racjonalnej argumentacji ma często tylko kliknąć w kilku rubrykach w liczbę na skali od 1 do 10. Przyznając uniwersytetowi dotację, liczy się studentów, doktorantów, przeprowadzone habilitacje, a mało 
kogo interesuje, czego uczy się studentów i co wnoszą do nauki rozprawy doktorskie czy habilitacyjne. Ta nowa jednostka chorobowa, którą nazwę „kwantofrenią”, ma swoje symptomy, zwane bibliometrią, naukometrią, parametryzacją itp. (Sztompka, 2014b, s. 21).

Kończąc ten wątek, przywołam jeszcze treść listu skierowanego do redakcji tygodnika PAUza (ukazującego się wyłącznie w sieci'), przed laty wielkiego entuzjasty parametryzacji i listy filadelfijskiej, fizyka A.K. Wróblewskiego:

W ubiegłym roku byłem członkiem jury dość prestiżowej nagrody fizycznej. Mieliśmy osiem zgłoszeń. Z tego aż sześciu kandydatów do nagrody podało w swych dokumentach tylko wartości „impact factor” i punkty ministerialne czasopism, w których opublikowali swoje prace, bez wyjaśnienia, czego dotyczyły badania i jakie wyniki zostały osiągnięte! To dowodzi spustoszenia, jakie w ciągu ostatnich lat dokonało się w umysłach wielu członków środowiska naukowego w Polsce. Oczywiście nasze jury odrzuciło od razu te 6 wniosków i wyłoniło laureata spośród pozostałych dwóch zgłoszonych kandydatów. Od kilkunastu lat walczę o wyeliminowanie z ocen osiągnięć naukowych takich pseudonaukowych substytutów jak punkty i „impakty”. Z wielką satysfakcją przyjąłem mocny tekst przemówienia profesora Piotra Sztompki na Kongresie Kultury Akademickiej („PAUza Akademicka” 247) [por. też Sztompka, 2014a, 2014b - J. M. B.], jak i obecne Oświadczenie władz Fundacji na rzecz Nauki Polskiej. Jest nadzieja, że może uda się odrobić straty i oprzeć ocenę osiągnięć naukowych na racjonalnych zasadach (Wróblewski, 2014, s. 2).

Mocna krytyka systemu oceny dokonań naukowych odwołującego się do „punktacji” (zwłaszcza DORA czy FNP) - czy to instytucji działających w sferze nauki, czy poszczególnych badaczy (o czym będzie mowa dalej) nie powinna jednak skłaniać do rezygnacji z posługiwania się wskaźnikami bibliometrycznymi i naukometrycznymi. Należy je tylko stosować rozsądnie i z umiarem. Natomiast na ewentualny zarzut, co z kosztami postępowania ewaluacyjnego poprowadzonego w trybie peer review (jak w Anglii) czy mieszanego: parametryczno-eksperckiego, odpowiem tak: albo dobrze to zrobimy i niestety będzie to i bardziej czasochłonne, i bardziej kosztowne, albo zrobimy to pośpiesznie i tanio, ale wówczas nie oczekujmy, że będzie to zrobione dobrze. Czy zadowolimy się w jeszcze jednej sferze naukowego życia bylejakością?

Nie wchodząc w szczegóły techniczne związane z drobnymi, ale dokuczliwymi problemami (jak powinno się to zrobić, i dlaczego właśnie tak,

${ }^{8}$ www.pauza.krakow.pl/ [4.09.2015]. 
w parametryzacji jednostek naukowych, która musi zakończyć się w 2017 r. zostało przedstawione w artykule: Antonowicz i Brzeziński, 2013). Chciałbym tu zwrócić uwagę jedynie na to, co powinno się uwzględniać w ocenie jednostek naukowych z grupy NHS.

Jeżeli dołączymy do listy JCR (Thomson Reuters) listę SCImago (Elsevier) i zrównoważymy je naukometrycznie (by nie dyskryminować czasopism NHS), usuniemy całkowicie nieprzydatną listę ERIH Plus, a także dobrze opracujemy listę B MNiSzW, to ta część (przeważająca) dorobku naukowego może z powodzeniem być oceniana parametrycznie. Oddalony zostanie tym samym zarzut o gorszym traktowaniu czasopism humanistycznych.

Trzeba też na nowo przyjrzeć się liczbie publikacji, które jednostka powinna przedstawiać do oceny. Nie uważam, że powinno to być aż 3N. Jeśli chodzi o monografie, to powinno się dążyć do znacznej redukcji ich liczby, aby możliwe było dokonanie ich oceny w trybie peer review. Dobrym rozwiązaniem jest też to, że jednostka sama wskazywałaby najważniejsze monografie, stanowiące niejako jej naukową wizytówkę. Zatem w części monograficznej dorobku naukowego ocena miałaby wyłącznie charakter peer review.

W NHS (ale też w pozostałych naukach) wyniki badań upowszechnia się poprzez ich publikowanie. Nawet gdy wygłasza się na prestiżowej konferencji ważny referat, to i tak przeobrazi się on w artykuł drukowany w bardzo dobrym, o światowym obiegu, czasopiśmie. Zatem na pytanie: gdzie?, odpowiem: przede wszystkim w czasopismach, a w następnej kolejności w monografiach. Wiem, że przynajmniej niektórzy przedstawiciele NHS odwrócą tę hierarchię ważności, przypisując większą rangę monografiom (wielkie syntezy itp.), jednak w mojej dyscyplinie (psychologia) są to czasopisma. Największy proporcjonalnie udział w całkowitej ocenie powinny mieć publikacje - przede wszystkim zaś artykuły naukowe. Ten udział widzę na poziomie $75 \%$.

Dodatkowo powinna być oceniana aktywność jednostki naukowej w zakresie pozyskiwania przez jej pracowników znaczących grantów Unii Europejskiej, NCN, NCBiR. Należy też uwzględniać uprawnienia do prowadzenia postępowań doktorskich i habilitacyjnych oraz udział pracowników jednostki w prowadzeniu przewodów doktorskich. Ostatnia parametryzacja jednostek z grupy NHS pokazała, że ocena zdobywania środków finansowych przez realizacje zleceń zewnętrznych nie różnicowała dobrych i słabych jednostek. Jest to zapewne ważne kryterium dla jednostek, które wchodzą w relacje biznesowe ze środowiskiem gospodarczym (nauki 
inżynierskie, rolnicze, ekonomiczne). Udział tej aktywności jednostki widzę na poziomie $15 \%$.

Wreszcie pozostawiłbym kryterium, które można by nazwać „Top Ten” - jednostka przedstawia swoje najważniejsze osiągnięcia (poza publikacjami i grantami; niekoniecznie musi ich być 10), które jakoś ją wyróżniają. To kryterium musi być oceniane wyłącznie w trybie peer review. Jego udział w całej ocenie to też $10 \%$. A zatem: $75 \%+15 \%+10 \%=100 \%$.

\subsection{Problem 2: Ustalenie kryteriów oceny badaczy}

Najwięcej krytyki zamknięty system biblio-naukometryczny zebrał za jego dość często bezkrytyczne, mechaniczne i spłaszczające ocenę, która została sprowadzona do sumy punktów - stosowanie wobec osiągnięć naukowych indywidualnych badaczy (zwłaszcza: DORA, FNP; Wróblewski, Żylicz, Sztompka). Ostrej krytyce poddano zwłaszcza tzw. sumaryczny Impact Factor $^{9}$ oraz praktykę sumowania przez rady wydziałów (i zachęconych przez nie kandydatów do stopnia doktora habilitowanego czy tytułu profesora) punktów, jak zwykło się pisać: „KBN/Ministerstwo/KEJN”, za publikacje autora. Żeby nie być gołosłownym, przytoczę przykład wzięty „z życia” takiej charakterystyki sporządzonej wedle ściśle biblio-naukometrycznego przepisu (oczywiście nie podaję danych osobowych, chociaż ten, a także inni badacze, nie miał wyboru; musiał tak sporządzić swój biblio-naukometryczny autoportret, gdyż takie było oczekiwanie rady wydziału):

Sumaryczny impact factor moich publikacji naukowych według listy Journal Citation Reports wynosi 22,256 (w tym po uzyskaniu tytułu [...] 21,668); sumaryczna liczba punktów MNiSzW/KBN jest równa 417, a IC (Index Copernicus - przyp. mój) - 192,668. Liczba cytowań moich prac według bazy Web of Science (bez autocytowań) jest równa 437.

Pozostawiam to bez komentarza. Ewentualnie proszę wrócić do wypowiedzi A.K. Wróblewskiego, który zaprotestował przeciwko takiemu

${ }^{9}$ Zresztą stosowanie tej nie do końca przemyślanej praktyki zaleca w swoim rozporządzeniu MNiSzW, gdy nakazuje uwzględnianie w opisie i recenzjach dorobku habilitantów podawanie wartości sumarycznego IF: „§ 4.3 sumaryczny impact factor publikacji naukowych według listy Journal Citation Reports (JCR), zgodnie z rokiem opublikowania”. Pora, aby je zmienić. Zob. Rozporządzenie Ministra Nauki i Szkolnictwa Wyższego z dnia 1 września 2011 r. w sprawie kryteriów oceny osiągnięć osoby ubiegającej się o nadanie stopnia doktora habilitowanego, Dz.U. poz. 1165. 
„syntetycznemu” przedstawianiu sylwetki badacza (fizyka, jak się można domyślać; mój przykład został zaczerpnięty z innej dyscypliny naukowej).

Jakie są zatem moje propozycje? Sprowadzają się do czterech punktów:

1. Dorobek naukowy każdego badacza z grupy NHS (a może niewiele się pomylę, jeżeli dodam, że także z innych dyscyplin naukowych) powinien być poddany ocenie przeprowadzonej w trybie peer review. Nie można dopuścić do tego, aby recenzent dorobku danego badacza zmuszony był postąpić podobnie jak A.K. Wróblewski. Musi się dokonać zmiana niedobrych nawyków niektórych rad wydziałów, które nakazują kandydatom do stopnia czy tytułu naukowego zbierać punkty ministerialne (nieważne za co i w jakiej kompanii zdobyte), aż uzyskają progową wartość owej sumy (np. 250 - jak to jest wymagane przez jedną z uczelni o profilu medycznym przy rozpatrywaniu wniosku o wszczęcie przewodu habilitacyjnego).

2. Na poddawany ocenie dorobek naukowy badacza powinny składać się następujące elementy:

a) podstawowe:

- publikacje: w czasopismach z list: JCR i SCImago oraz z listy krajowej oraz monografie i podręczniki akademickie;

- granty (UE, NCN, NCBiR);

- udział w kształceniu kadr naukowych: promotorstwo i recenzowanie prac na stopień i tytuł (tylko pracownicy samodzielni);

b) pomocnicze:

- referaty: tylko z konferencji o zasięgu międzynarodowym i co najmniej krajowym;

- postery: tylko do doktora włącznie;

- udział w pracach organizacji i stowarzyszeń naukowych.

3. Uwzględnienie - ale pomocniczo i w kontekście analizy jakościowej dorobku - wskaźników: h-Hirscha (z WoS i Google Scholar: włącza także prace w języku polskim, artykuły, monografie, rozdziały w pracach zbiorowych oraz podręczniki akademickie, co szczególnie istotne dla przedstawicieli grupy NHS), liczby cytowań. Zakaz: IF oraz sumaryczny IF.

4. Ocena peer review powinna odnosić się jedynie do pewnej liczby wybranych przez samego badacza - i uznanych przez niego za najważniejsze - publikacji (np. 10: dr $\rightarrow$ hab.; 15: dr hab. $\rightarrow$ prof.). Ekspert powinien być zobowiązany do pogłębionej oceny każdej ze wskazanych przez badacza publikacji. Ponieważ coraz częściej spotykamy się z pracami zespołowymi (zwłaszcza w eksperymentalnej psychologii), ekspert powinien też dokonać (na podstawie wskazania badacza-współautora) oceny wkładu danego badacza w powstanie danej publikacji (czy był on autorem pomysłu, czy 
autorem analiz statystycznych, albo wyłącznie obsługiwał aparaturę pomiarową). Ów udział powinien być potwierdzony przez współautorów, a nie tylko stwierdzony przez ocenianego badacza. Zresztą od jakiegoś czasu upowszechnia się, także w polskich czasopismach naukowych z NHS, zwyczaj drukowania na pierwszej stronie artykułu informacji o udziale poszczególnych współautorów w powstaniu pracy - jest to dobry sposób na ochronę przed manipulacją udziałami współautorskimi [np. dwa czasopisma psychologiczne wydawane przez Instytut Psychologii UG: Current Issues in Personality Psychology (wychodzi od 2013 r.) oraz Health Psychology Report (wychodzi od 2013 r.) $]^{10}$.

\section{Podsumowanie}

Problem niedostrzegania przez instytucje państwa odrębności NHS (względnie pozorowania postrzegania tej odrębności) bierze się z fałszywego przekonania o wyższości nauk „prawdziwych” (science) nad innymi przejawami aktywności osób reprezentujących NHS, które są one skłonne sklasyfikować jako działalność udającą naukę, imitującą warsztat prawdziwej nauki, ale tak naprawdę przynależną do sfery sztuk (arts). Stąd też wielka niechęć, stale pogłębiana, aby prawdziwe czasopisma naukowe (te z listy JCR) znacząco wyróżniać na tle pozostałego piśmiennictwa. A problem docenienia wartościowych - użyję jednak tego określenia: naukowo - monografii humanistycznych to według nich problem marginalny. W „prawdziwej” nauce monografie schodzą na dalszy plan. Sporo racji mieli więc autorzy krytycznych wystąpień w trakcie zorganizowanego 26 lutego 2014 r. w Warszawie przez minister ds. nauki „Okrągłego Stołu Humanistyki” (choć jako jego uczestnik nie ze wszystkimi wypowiedziami się zgadzałem; Brzeziński, 2014).

Chciałbym tu zająć stanowisko (Brzeziński, 2009) - i mój pogląd nie jest wśród filozofów nauki odosobniony (por. np. Nowak, 1998) - że zasadne jest mówienie o równoważności poznawczej (jedności) nauk humanistycznych i społecznych oraz nauk przyrodniczych. I nie powinna nas wprowadzać w błąd ani pozorna osobliwość przedmiotu poznania naukowego, ani metody tego poznania. To, że nauki społeczne interesuje człowiek (w sensie determinant jego zachowania), a humanistykę, w przeważającej mierze,

10 http://wns.ug.edu.pl/wydzial/instytuty_wns/instytut_psychologii/dzialalnosc_naukowa/czasopisma [4.09.2015]. 
jego wytwory należące do szeroko pojmowanej kultury duchowej i materialnej, nie stanowi, co chcę mocno podkreślić, zasadniczej przeszkody w podejmowaniu naukowej refleksji. Nie da się zatem usprawiedliwić, za pomocą argumentów metodologicznych, traktowania nauk humanistycznych i społecznych jako „mniej naukowych”, by nie powiedzieć: „gorszych”. Nie można też mówić, iż dostarczane przez nie rezultaty są banalne, bo odnoszą się do mało ważnej strony praktyki społecznej. Tak samo nie można mówić, że jako niepoddające się (przynajmniej niektóre z nich) intersubiektywnym procedurom weryfikacji, konfirmacji czy falsyfikacji wypracowanym na gruncie metodologii nauk przyrodniczych i ścisłych nie zasługują na równie poważne traktowanie. Nauki z grupy NHS nie są ani gorsze, ani lepsze od nauk ścisłych, przyrodniczych czy technicznych. I jedne, i drugie mogą mieć gorsze jakościowo ustalenia. I tylko tyle.

Rzecz jasna można dostrzec różnice w charakterystykach warsztatowych poszczególnych dyscyplin naukowych. I nie ma potrzeby wskazywania tu na owe różnice, gdyż nie są one poznawczo nośne. Charakteryzują one jedynie specyficzną drogę dojścia przedstawicieli każdej z dyscyplin naukowych do wyniku naukowego. Odmienne tedy są, co zrozumiałe, preferowane przez historyków, psychologów czy biologów metody zbierania i analizy danych empirycznych. Mówienie zatem w tym kontekście o „odmienności” nauk przyrodniczych oraz humanistycznych i społecznych jest po prostu banalne.

Chciałbym, aby „starsi bracia” (fizycy, chemicy, technicy itp., choć to filozofowie są tak naprawdę tymi najstarszymi braćmi) oraz państwowi decydenci ową odmienność (w sensie pozytywnym) nauk humanistycznych i społecznych dostrzegali. Mało tego, chciałbym, by postawie rozumiejącej owe różnice towarzyszyła gotowość do dostrzegania ich potrzeb finansowych i aby miało to wpływ na odejście od dotychczasowych praktyk dyskryminujących czy nawet wykluczających.

Zaś w praktyce ewaluacyjnej konsekwencją uznania osobliwości NHS na poziomie badań naukowych musi być brak zgody na użycie tylko jednego, uniwersalnego narzędzia do oceny wartości efektów działalności uczonych i zatrudniających ich instytucji - zwłaszcza gdy chodzi o ocenę jakości publikacji, tego najważniejszego „produktu” pracy badaczy z obszaru NHS. Jeżeli będzie to narzędzie stworzone na gruncie nauk ścisłych i przyrodniczych (a taka jest geneza stosowanych dziś narzędzi), to trudno oczekiwać trafnych wyników jego użycia. Co najwyżej będzie to tylko częściowa trafność. Narzucanie z zewnątrz, spoza dziedziny, określonych standardów publikacyjnych i ewaluacyjnych to droga donikąd. Bezwzględny priorytet publikacji anglojęzycznych nad publikacjami w języku polskim, a nawet de- 
precjonowanie czy ośmieszanie publikowania w języku polskim nie jest konstruktywne. Ale czy musi to oznaczać rezygnację z publikowania osiągnięć naukowych powstałych w NHS w wydawnictwach (monografie i artykuły) w językach obcych? Nie należy popadać w drugą skrajność. Trzeba jedynie lepiej dostosować narzędzia ewaluacyjne do specyfiki NHS. W niniejszym artkule przedstawiłem taką, jak mniemam, konstruktywną propozycję.

\section{Literatura}

Alberts, B. (2013). Impact factor distortions. Science, 340(6134), 787.

Antonowicz, D., Brzeziński, J.M. (2013). Doświadczenia parametryzacji jednostek naukowych z obszaru nauk humanistycznych i społecznych 2013 - z myślą o parametryzacji 2017. Nauka, 4, 51-85.

Bizukojć, M. (2014). Akademia Młodych Uczonych wobec Deklaracji z San Francisco. Nauka, 4, 101-104.

Brzeziński, J. (2009). Czy nauki humanistyczne i społeczne są dostatecznie naukowe, aby je należycie finansować z budżetu państwa? Nauka, 1, 75-85.

Brzeziński, J. (2014). Formacyjna rola humanistyki. Forum Akademickie, 3, 17-19.

DORA (2012). San Francisco Declaration on Research Assessment. Putting science into the assessment of research. http://www.ascb.org/dora-old/files/SFDeclarationFINAL. pdf [4.09.2015].

FNP, Fundacja na Rzecz Nauki Polskiej (2014). Oświadczenie władz Fundacji na rzecz Nauki Polskiej. http://www.fnp.org.pl/assets/O\%C5\%9Bwiadczenie-Rady-i-Zarz\%C4\%85du-FNP.pdf [4.09.2015].

Kolasa, W.M. (2011). Retrospektywny indeks cytowań w humanistyce. Koncepcja, metoda, zastosowania. Przegląd Biblioteczny, 4, 466-486.

Kulczycki, E. (2014). Zasady oceny czasopism humanistycznych i ich rola w parametryzacji jednostek naukowych. Nauka, 3, 117-140.

Nowak, L. (1998). O ukrytej jedności nauk społecznych i nauk przyrodniczych. Nauka, 1, 11-42.

Rozporządzenie Ministra Nauki i Szkolnictwa Wyższego z dnia 8 sierpnia 2011 r. w sprawie obszarów wiedzy, dziedzin nauki i sztuki oraz dyscyplin naukowych i artystycznych. Dz.U. poz. 1065.

Rozporządzenie Ministra Nauki i Szkolnictwa Wyższego z dnia 1 września 2011 r. w sprawie kryteriów oceny osiągnięć osoby ubiegającej się o nadanie stopnia doktora habilitowanego, Dz.U. poz. 1165.

Rozporządzenie Ministra Nauki i Szkolnictwa Wyższego z dnia 13 lipca 2012 r. w sprawie kryteriów i trybu przyznawania kategorii naukowej jednostkom naukowym. Dz.U. poz. 877.

Sztompka, P. (2014a). Uniwersytet współczesny; zderzenie dwóch kultur. Nauka, 1, 7-18. Sztompka, P. (2014b). Po Kongresie Kultury Akademickiej. Nauka, 2, 14-25.

Wilkin, J. (2013). Ocena parametryczna czasopism naukowych w Polsce - podstawy metodologiczne, znaczenie praktyczne, trudności realizacji i perspektywy. Nauka, 1, 45-54. 
Wiśniewski, A. (2006). Dlaczego humaniści nie są wielbłądami, czyli o ocenie parametrycznej jednostek naukowych. Nauka, 1, 121-128.

Woleński, J. (2013). Uwagi o ewaluacji czasopism naukowych. Nauka, 1, 55-68.

Wróblewski, A.K. (2014). Listy do Redakcji „PAUzy Akademickiej”. PAUza Akademicka, 249.

Żylicz, M. (2008). Wypowiedzi w dyskusji o polskich czasopismach naukowych. PAUza Akademicka, 14, 3.

ekulczycki.pl/warsztat_badacza/erih-plus-zostal-uruchomiony/ [4.09.2015].

http://scientific.thomsonreuters.com/cgi-bin/jrnlst/jloptions.cgi?PC=Master [4.09.2015].

http://wns.ug.edu.pl/wydzial/instytuty_wns/instytut_psychologii/dzialalnosc_naukowa/ czasopisma [4.09.2015].

http://www.scimagojr.com/ [4.09.2015].

https://dbh.nsd.uib.no/publiseringskanaler/erihplus/discipline/list [4.09.2015]. 